\title{
Apresentação
}

\section{N. 23 (vol.17) - Literatura contemporânea}

Este número da Pandaemonium Germanicum dedica especial atenção à literatura contemporânea de língua alemã. A produção literária dos últimos anos apresenta questões que vão muito além da Popliteratur, do que se convencionou chamar Wenderoman ou do confronto com a história alemã do século XX. Os livros analisados nos artigos, por exemplo, são dedicados ao direito, à história e à arte, a utopias e distopias, à sociedade contemporânea, mundos fantásticos e à autobiografia e possuem uma impressionante disposição para enfrentar os mais complexos problemas de seu entorno e de sua história. Nesse sentido, cabe notar que a palavra Gedankenexperiment (experimento mental) ocorre em mais de um texto desta edição da Pandaemonium. Este número reúne oito estudos sobre a literatura contemporânea de língua alemã, além de dois artigos sobre Walter Benjamin, uma interpretação de um texto do barroco e um artigo sobre as relações entre Flusser e Freud.

No artigo que abre esta edição, Sonja ARNOLD, em "Zur Beziehung zwischen Literatur und Recht in der deutschsprachigen Gegenwartsliteratur" [The Relationship between Law and Literature in Contemporary German Literature], analisa a especificidade da configuração literária de problemas e temas jurídicos e seus possíveis efeitos sobre o âmbito do Direito. Por meio das análises de obras de Juli Zeh (Spieltrieb, 2004) e Ferdinand von Schirach (Verbrechen, 2009; Tabu, 2013), bem como de suas adaptações para a televisão, Arnold mostra que a literatura pode servir como campo legítimo de análise de complexas questões jurídicas (na representação ficcional de julgamentos ou crimes, por exemplo), como lugar de questionamento de concepções de justiça e suas consequências, e como instrumento de reflexão sobre os discursos jurídico e literário.

A reflexão sobre a história entra em cena no artigo de Helmut GALLE, "Geschichtsdarstellung in der Gegenwartsliteratur: Florian Illies' Pop-Chronik der Welt von Gestern" [Representation of History in Contemporary Literature: Florian Illies's Pop-Chronicle of the Belle Epoque]. Galle analisa o livro 1913. Der Sommer des 
Jahrhunderts [1913. O verão do século], publicado em 2012, de Florian Illies, que se utiliza de recursos literários para reconstruir o momento cultural que antecedeu à Primeira Guerra Mundial. Illies não perde de vista as informações históricas, nem inventa dados ou personagens, mas ficcionaliza as cenas que pretende abordar. $\mathrm{O}$ resultado, segundo Galle, é uma representação histórica "contrafactual" e paradoxal, pois, através de dados factuais, permite ao leitor imaginar uma Europa um instante antes de seu inverno histórico.

A sociedade contemporânea é tema da análise de Valeria S. PEREIRA em "Utopia ou distopia? A ansiedade e o vazio em Schimmernder Dunst über CobyCounty de Leif Randt" [Utopia or dystopia? Anxiety and emptiness in Leif Randt's Schimmernder Dunst über CobyCounty]. O romance de Randt, que recebeu o prêmio Ingeborg Bachmann em 2011, descreve uma sociedade de consumo "perfeita", ameaçada apenas por uma possível catástrofe natural. Segundo PEREIRA, Schimmernder Dunst não se configura nem como um texto utópico, nem como uma obra distópica, pois, embora possua traços típicos dos dois gêneros, o romance aproxima-se mais de um "diagnóstico" desapaixonado - e talvez por isso, inquietante - da atual sociedade de consumo.

Dois artigos abordam a obra de Christian Kracht: o estudo de Daniel BonOMO sobre "Vazio e fastio em Faserland" [Emptiness and fastidiousness in Christian Kracht's Faserland], e o de Michael KorfmANn sobre "Imperium (2012) e a questão da auto(r)encenação" [Christian Kracht's novel Imperium and the question of selfenactment]. $\mathrm{O}$ artigo de Bonomo concentra-se no primeiro romance de Kracht, escrito em 1995 e quase considerado um "clássico" da literatura pop, o de Korfmann examina a obra de um autor já premiado e enfatiza sua autoencenação, tema igualmente mencionado por Bonomo. Faserland seria, conforme Bonomo, um romance do tédio característico da Generation Golf, do fastio causado pela vida atual; Imperium, conforme Korfmann, a configuração irônica de uma sociedade alternativa, talvez já imaginada em outras obras e declarações de Kracht. Interessante é notar que, nos dois estudos, o estabelecimento de uma relação forte dos livros de Kracht com a tradição literária oferece a possibilidade de uma interpretação que não se deixa distrair pela figura pública do autor.

Outro tipo de autoencenação, mais fantástica e divertida, encontra-se na obra de Walter Moers, discutida no artigo "Fantasia e metaficcionalidade nos romances de 
Zamonien de Walter Moers" [Fantasy and metafictionality in Walter Moers' Zamonien Novels], de Laura Alves do PRADO. Prado analisa o livro Die Stadt der träumenden Bücher [A cidade dos livros sonhadores], que, segundo Walter Moers foi escrito por um "Lindwurm", dragão de duas patas, chamado Mythenmetz. O jogo com o fantástico, reforçado por Moers a cada novo livro da série, dirige a atenção do leitor para a própria construção ficcional e, assim, a reflexão sobre a ficcionalidade e a medialidade do livro dá-se através da própria ficção.

Em "Autobiographie, Autofiktion, Metafiktion und Literatur. Der Fall Stadt der Engel von Christa Wolf" [Autobiography, autofiction, metafiction and literature. The case of Stadt der Engel by Christa Wolf], Celeste Ribeiro de SouSA trata da dissolução das fronteiras entre o discurso biográfico, autobiográfico, histórico e ficcional no romance Stadt der Engel oder The Overcoat of Dr. Freud., de Christa Wolf, publicado em 2010. Conforme a análise apresentada, Wolf, seguindo uma forte tendência da literatura contemporânea, transforma ficcionalmente cenas ou situações com base factual, a fim de abrir espaço a uma reflexão mais aprofundada sobre a própria vida e a história alemã.

O crítico Marcel Reich-Ranicki é tema do trabalho de Klaus EGGENSPERGER, que relata o itinerário tortuoso através do qual Ranicki se tornou um dos mais respeitados e, ao mesmo tempo, mais polêmicos críticos literários da Alemanha. O artigo "Para entender Reich-Ranicki" [Understanding Reich-Ranicki] procura analisar as relações entre a defesa do cânone da literatura e a tentativa, feita por Ranicki, de aproximar a literatura ao público em geral; também analisa o papel da indústria cultural da qual o crítico, mesmo a contragosto, fazia parte.

A obra de outro crítico, Walter Benjamin, é analisada em dois artigos. No primeiro, estabelece-se uma forte relação entre Benjamin e Marcel Proust, relação detalhadamente estudada por Maria BELFORTE em "Imágenes del despertar. La influencia proustiana en Das Passagen-Werk de Walter Benjamin" [Images of awakening. The Proustian influence in Benjamin's Das Passagen-Werk]. Segundo a autora, é sobretudo em Proust que Benjamin encontra noções fundamentais de seus escritos, como a da memória involuntária, do despertar e da aura, atribuindo a elas, porém, um caráter materialista. Belforte enfatiza, assim, uma leitura política da relação que Benjamin estabeleceu com a obra de Proust. 
Miguel VEDDA assina o artigo "La gran grieta del mundo". Siegfried Kracauer, Walter Benjamin y los debates sobre la figura del intelectual [The great Rift of the World". Siegfried Kracauer, Walter Benjamin and the Debates about the Figure of the Intellectual]. O artigo reconstrói, por meio do exame de obras de Krakauer e Benjamin, sua teoria sobre os intelectuais, com ênfase na politização não dogmática.

A questão política também determina o trabalho de Dionei MATHIAS sobre "A diversidade do ódio: Masaniello de Christian Weise" [The Diversity of Hate in Christian Weise's Masaniello], autor do barroco alemão. Mathias estuda as diversas configurações que o ódio adquire na peça, procurando analisar suas implicações para o discurso político da época.

Na seção de Tradução, Pedro Heliodoro TAVAREs, em "Flusser com Freud: Tradução, Sujeito e Cultura" [Flusser with Freud: Translation, Subject and Culture], analisa as convergências entre o pensamento dos dois autores a partir da noção do "malestar" e da possibilidade de seu enfrentamento através das "capacidades criativas da linguagem e da tradução".

Encerra este número a resenha de Patrícia da Silva SANTOS sobre a tradução do livro A Rosa Branca, de Inge Scholl, lançada no Brasil em 2013.

São Paulo, 08 de junho de 2014, Juliana P. Perez 